\title{
How Safe is Your House? ${ }^{1}$
}

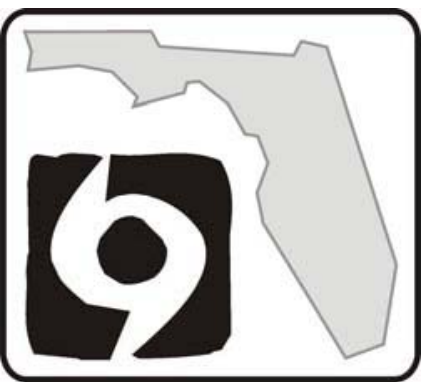

Hal S. Knowles, III, Kathleen C. Ruppert, Karla A. Lenfesty, and Barbara Haldeman ${ }^{2}$

Living with hurricanes is a common event for Florida's residents. Researchers have found four major areas where homes commonly fail as a result of hurricane-force winds. Proper hurricane preparation takes action to strengthen these areas.

\section{What Should Be Done to Prepare this House for a Hurricane? (Hint: Turn to the back for answers)}

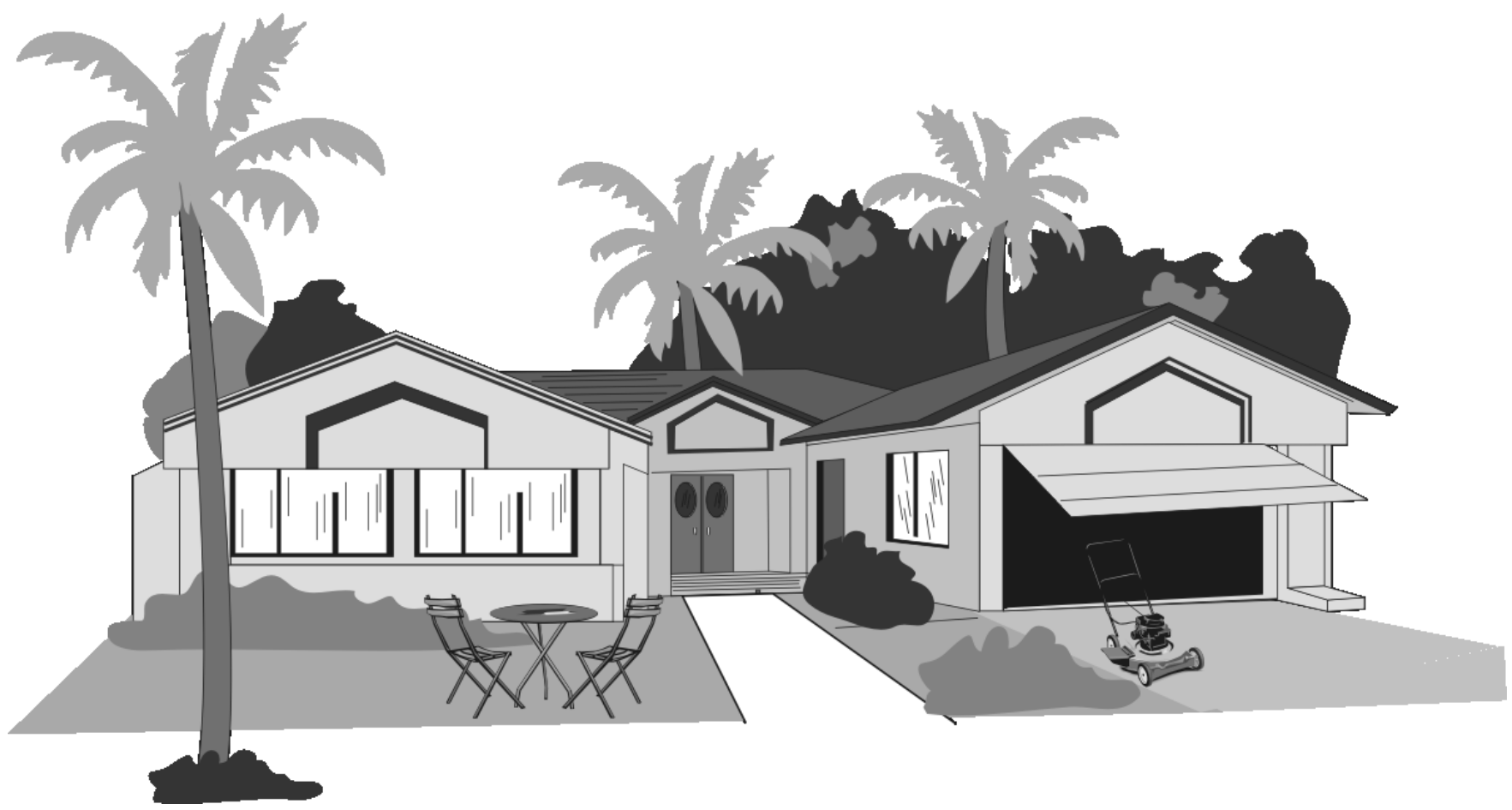

1. This document ABE374 is Part 1 of 5 in the Education + Action = Wind Damage Mitigation series. Publication date: November 2005.

2. Hal S. Knowles, III, research associate, Program for Resource Efficient Communities; Kathleen C. Ruppert, Extension scientist, Program for Resource Efficient Communities; Karla A. Lenfesty, family and consumer sciences agent, St. Lucie County Cooperative Extension, Institute of Food and Agricultural Sciences, University of Florida; Barbara Haldeman, editorial assistant, Florida Energy Extension Service.

Publication partially funded from a Florida Department of Community Affairs Residential Construction Mitigation Program Grant.

The Institute of Food and Agricultural Sciences (IFAS) is an Equal Opportunity Institution authorized to provide research, educational information and other services only to individuals and institutions that function with non-discrimination with respect to race, creed, color, religion, age, disability, sex, sexual orientation, marital status, national origin, political opinions or affiliations. U.S. Department of Agriculture, Cooperative Extension Service, University of Florida, IFAS, Florida A. \& M. University Cooperative Extension Program, and Boards of County Commissioners Cooperating. Millie Ferrer-Chancy, Interim Dean 
Windows: protected with shutters
Outdoor Items:

secured inside the house or garage

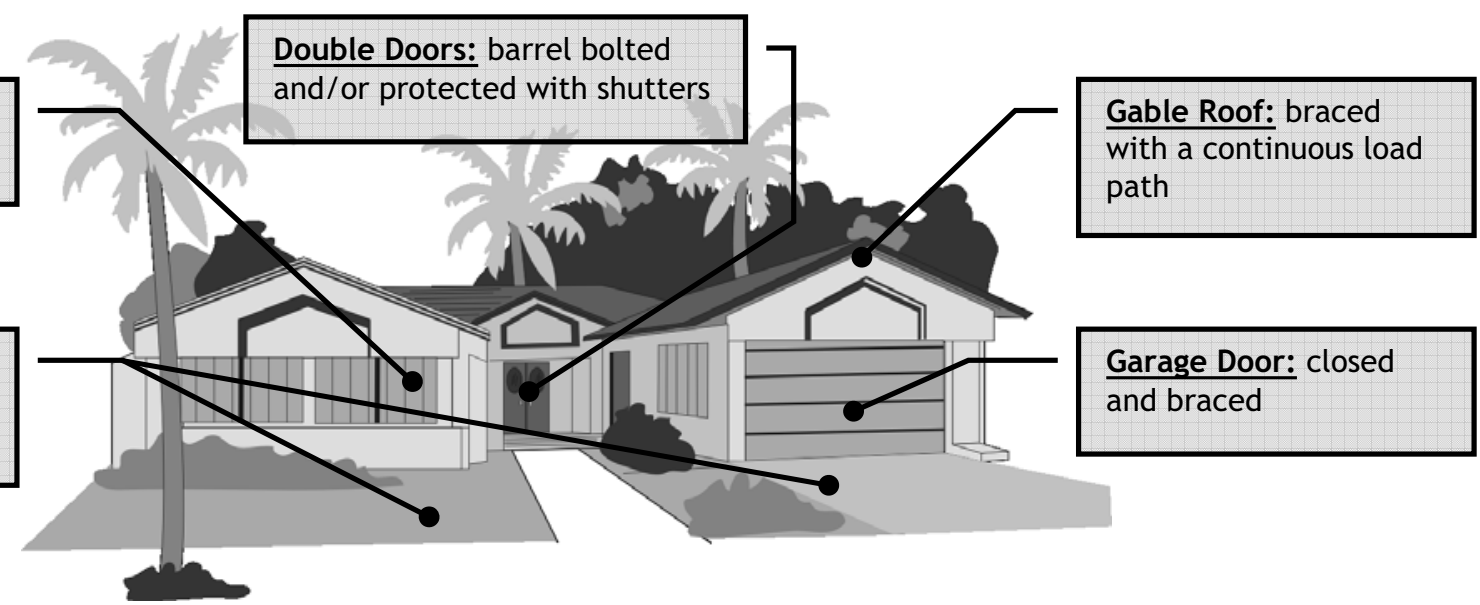

To learn more about these items, ask a County Cooperative Extension agent for the individual documents in this series.

\section{What Can You Do to Prepare Yourself?}

All families should have a disaster kit ready before a storm hits. Refresh your kit every 6 months. Here's a checklist so you can be prepared whether you evacuate or stay home:

- Seven-day supply of food that does not need refrigeration or cooking.

- Seven-day supply of water (one gallon per person per day).

- Seven-day supply of clean clothes and shoes.

- Sleeping items (blankets, pillows, etc.).

- Toiletries (toothbrush, toothpaste, soap, deodorant, shampoo/conditioner, etc.).

- Cash (in case ATMs/banks are closed).

- First aid kit (including basic medicines and prescription drugs).

- Operable vehicle with a full gas tank.

- Radio (battery powered or wind-up).

- Flashlight (batter powered or wind-up).

- Spare batteries.

- Tools (for basic car and/or house repair).

- Important documents stored in a waterproof container (medical records, insurance records, Social Security cards, etc.)

- Pet care items (food, water, cage, leash, immunization record, etc.).

- Any other specialty items.
Some protective measures can bring insurance savings in Florida. Visit the Florida Department of Community Affairs Web site for more info: www.FloridaWindIncentives.org.

\section{Other Resources}

For additional information on ways to prepare your property and your family for a hurricane, we recommend the following Web sites:

University of Florida | Disaster Handbook http://disaster.ifas.ufl.edu/

University of Florida | Storm Preparation for Landscapes

http://hort.ifas.ufl.edu/woody/stormprep.htm

Federal Alliance for Safe Homes

www.flash.org

Federal Emergency Management Agency | Disaster Prevention \& Preparation Library www.fema.gov/library/prepandprev.shtm

Florida Division of Emergency Management Information Page

www.floridadisaster.org/DEMinformation.htm

Institute for Business and Home Safety

www.ibhs.org 